\title{
ANALISA YURIDIS SENGKETA CIPTAAN ANTARA YAYASAN HWA ING FONDS DENGAN BUDI HALIMAN HALIM
}

\author{
Djumikarsih \\ Fakultas Hukum Universitas Brawijaya Malang \\ e-mail:djumikarsih@yahoo.com
}

\begin{abstract}
ABSTRAK
Dalam penulisan ini akan dibahas bahwa hak cipta itu memberikan perlindungan hukum kepada pemiliknya sebagai pemegang hak cipta dari ciptaannya, yang berdasar pada ketentuan pada Pasal 12 ayat 1 Undang-Undang Hak Cipta, yang mana termasuk karya seni logo. Perlindungan hukum yang diberikan kepada pemegang hak cipta itu bukan untuk pendaftarannya, namun untuk ide-ide dan gagasan yang mana terealisasi dalam bentuk penciptaan, hal ini dikarenakan ciptaan itu terlahir dari gagasan yang kemudian terwujud dan memiliki ciri yang khas dan khusus. Berkenaan dengan kasus Yayasan Hwa Ing Fonds dengan Budi Haliman Halim, sebenarnya Yayasan Hwa Ing Fonds masih berhak atas logo ciptaannya yang berbentuk logo perisai dengan bentuk matahari bersinar di benteng kiri dan kanan yang bertuliskan Cina Hua dan Yuan, yang telah digunakan sejak tahun 1929. Sementara itu Budi Haliman Halim mendaftarakan logo yang sama karena dilihat belum ada pendaftaran, pendaftaran yang dilakukan Budi Haliman Halim ini tidak memperoleh perlindungan hukum dari Undang-Undang Hak Cipta, dan penciptaannya terdaftar tidak asli karena logo tersebut diciptakan oleh Yayasan Hwa Ing Fonds.
\end{abstract}

Kata Kunci: hak cipta, logo, pendaftaran, ciptaan, perlindungan hukum.

\begin{abstract}
In this paper will be discussed about the copyright which is giving a legal protection to the owner as the copyright holder of the creation, and based on Article 12 (1) Copyright Law (UUHC) which also regulate about logo. Legal protection which is given to the copyright holder was not for the registration, but given for the ideas which are resulting into creation, this is because creations were born from ideas and has a distinctive and special traits. Related to Foundation Hwa Ing Fonds and Budi Haliman Halim case, actually Foundation Hwa Ing Fonds still has the copyright of the created shield-shaped logo background with the sun shining on the left and right castle and it says Cina Hua and Yuan has been used since 1929. Meanwhile, Budi Haliman Halim registered the same logo because he saw no registration done for the related logo, the registration done by Budi Haliman Halim did not obtain legal protection from UUHC, and the logo registered as fake because the logo was created by the idea of Foundation Hwa Ing Fonds.
\end{abstract}

Keywords: creation, legal protection, registration, logo, copyright.

\section{PENDAHULUAN}

Ciptaan itu didefinisikan sebagai hasil dari setiap karya pencipta yang mana menunjukkan keasliannya dalam lapangan ilmu pengetahuan seni atau sastra, sebagaimana Pasal 1 angka 3 Undang-Undang No. 19 Tahun 2002 tentang Hak Cipta (yang selanjutnya disingkat UUHC). Ciptaan tidak akan ada dengan sendirinya melainkan sengaja untuk dicipta oleh pihak yang dinamakan pencipta. Pencipta menurut Pasal 1 huruf 2 UUHC adalah seorang atau beberapa orang secara bersama-sama yang atas inspirasinya melahirkan suatu ciptaan berdasarkan kemampuan pikiran, imajinasi, kecekatan, keterampilan, atau keahlian yang dituangkan ke dalam bentuk yang khas dan bersifat pribadi. Jadi suatu ciptaan bisa dihasilkan oleh orang perseorangan maupun secara bersamasama, sehingga jika suatu ciptaan dihasilkan secara bersama-sama, maka masing-masing bisa disebut sebagai pencipta.

Peraturan perundang-undangan akan memberikan perlindungan kepada pemegang hak cipta, menurut 
Pasal 1 angka 1 UUHC, yaitu hak eksklusif bagi pencipta atau penerima hak untuk mengumumkan atau memperbanyak ciptaannya atau memberikan izin untuk itu dengan tidak mengurangi pembatasanpembatasan menurut peraturan perundang-undangan yang berlaku. Suatu ciptaan dapat diciptakan oleh seseorang atau beberapa orang secara bersama-sama, sesuai dengan ketentuan Pasal 1 angka 2 UUHC yang menentukan pencipta adalah seorang atau beberapa orang secara bersama-sama yang atas inspirasinya melahirkan suatu ciptaan berdasarkan kemampuan pikiran, imajinasi, kecekatan, ketrampilan, atau juga keahlian yang dituangkan ke dalam bentuk yang khas dan bersifat pribadi.

Dibahasnya mengenai ciptaan ini ada kaitannya dengan sengketa antara Yayasan Hwa Ing Fonds dengan Budi Haliman Halim sebagai pemilik dari pelatihan bahasa KOTA BAHASA atas penggunaan logo berbentuk perisai berlatar belakang matahari bersinar. Dengan benteng bagian atas kiri kanannya terdapat tulisan Cina yaitu Hua dan Yuan. Di bawah benteng juga ada tulisan Arise Shine. Yayasan Hwa Ing Fonds didirikan pada 19 Desember 1929 itu telah menggunakan logo Aires Shine atau CES itu, namun kenyataannya sejak tahun 2001 Budi Haliman Halim menggunakan logo milik Yayasan tersebut.

Yayasan Hwa Ing Fonds mencoba menyelesaikan permasalahannya dengan melalui cara damai, namun Budi Haliman Halim menolaknya dengan alasan bahwa logo tersebut telah didaftarkan pada Dirjen HKI. Akhirnya pemilik Yayasan Hwa Ing Fonds melaporkan Budi Haliman Halim pada kepolisian, dan kasus itu pun bergulir ke meja hijau bahkan hingga tingkat Peninjauan Kembali, Budi Haliman Halim dinyatakan bersalah melakukan perbuatan melanggar hak cipta. Namun menurut pihak pemilik Yayasan Hwa Ing Fonds ada hal yang aneh, karena Pengadilan Negeri menganulir putusan Mahkamah Agung dan menyatakan Budi Haliman Halim bukan sebagai penjiplak logo tersebut dengan pertimbangan hukum memang Yayasan Hwa Ing Fonds dinyatakan sebagai pencipta logo sebagaimana termaktub dalam Putusan MARI No. 012 PK/N/HAKI/2005 tanggal 8 Januari 2006. Dengan fakta itu, maka berlakulah ketentuan dalam Pasal 30 ayat 3 UU No. 19 Tahun 2002 bahwa masa berlaku atau masa perlindungannya telah berakhir selama 50 tahun.

Berdasarkan uraian sebagaimana tersebut di atas, maka permasalahan yang dibahas adalah bagaimana perlindungan hukum terhadap suatu ciptaan. Apakah Yayasan Hwa Ing Fonds masih berhak atas logo berbentuk perisai berlatarbelakang matahari bersinar dengan benteng bagian atas kiri dan kanannya terdapat tulisan Cina Hua dan Yuan yang digunakan oleh Budi Haliman Halim ditinjau dari UUHC.

\section{PEMBAHASAN}

\section{Perlindungan Hukum atas Suatu Ciptaan Logo Sebagai Ciptaan yang Dilindungi oleh Undang- Undang}

Dibahasnya logo sebagai suatu ciptaan adalah untuk mengetahui lebih lanjut kasus mengenai logo berbentuk perisai berlatarbelakang matahari bersinar, dengan benteng bagian atas kiri dan kanannya terdapat tulisan Cina Hua dan Yuan, di bawah benteng juga ada tulisan Arise Shine (dikenal logo Aires Shine atau CES), yang disengketakan antara Yayasan Hwa Ing Fonds didirikan 1929 dengan Budi Haliman Halim.

Berdasarkan pada Pasal 1 ayat 1 UUHC yang mana menyatakan hak cipta adalah hak eksklusif bagi pencipta atau penerima hak untuk mengumumkan atau memperbanyak ciptaannya atau juga memberikan izin untuk itu dengan tidak mengurangi pembatasanpembatasan menurut peraturan perundang-undangan yang berlaku. Pencipta adalah seorang atau beberapa orang bersama-sama dan atas inspirasinya melahirkan ciptaan berdasar kemampuan dari pikiran, imajinasi, kecekatan, keterampilan, atau juga keahlian yang dituangkan ke dalam bentuk yang khas dan bersifat pribadi (Pasal 1 angka 2). Ciptaan adalah hasil setiap karya pencipta yang menunjukkan keasliannya dalam lapangan ilmu pengetahuan, seni, atau sastra (Pasal 1 angka 3$)$.

Ciptaan yang dilindungi UUHC khususnya Pasal 12 ayat 1 sebagai berikut, dalam undang-undang ini ciptaan yang dilindungi adalah ciptaan dalam bidang ilmu pengetahuan, seni, dan sastra, yang mencakup: buku, program komputer, pamflet, perwajahan atau layout karya tulis yang diterbitkan, dan semua hasil karya tulis lain; ceramah, kuliah, pidato, dan ciptaan lain yang sejenis dengan itu; alat peraga yang dibuat untuk kepentingan pendidikan dan ilmu pengetahuan; lagu atau musik dengan atau tanpa teks; drama atau drama musikal, tari, koreografi, pewayangan, dan pantomim; seni rupa dalam segala bentuk seperti seni lukis, gambar, seni ukir, seni kaligrafi, seni pahat, seni patung, kolase, dan seni terapan; arsitektur; peta; seni batik; fotografi; sinematografi; terjemahan, tafsir, saduran, bunga rampai, database, dan karya lain dari hasil pengalihwujudan.

Logo termasuk ciptaan sebagai perwujudan seni rupa dalam segala bentuk seperti seni lukis, gambar, seni ukir, kaligrafi, pahat, patung, kolase, dan terapan sebagaimana Pasal 12 ayat 1 huruf f UUHC. 
Namun demikian, tidak semua ciptaan dilindungi hak cipta. Dalam hal ini sesuai ketentuan Pasal 1 angka 2 dan angka 3 UUHC tersebut, terkait suatu standar perlindungan hak cipta atau standards of Copyright's ability. Ketentuan tersebut diterjemahkan lebih lanjut oleh Rahmi Jened sebagai berikut (Earl W. Kinter dan Jack Lahr, 1993:346-349): 1. Keaslian atau originalitas. Kata asli atau uji keaslian bukan berarti karya tersebut harus betul baru atau unik. Bahkan suatu karya yang didasarkan pada sesuatu yang telah menjadi miliknya umum mungkin saja masih asli; 2. Kreativitas. Kreativitas sebagai suatu patokan kemampuan suatu karya dapat diberikan hak cipta adalah menunjuk secara sederhana suatu derajat tinggi ukuran keaslian. Meskipun suatu karya merupakan tiruan yang benar-benar biasa suatu karya sebelumnya, mungkin dikatakan tidak asli, jika suatu tiruan membutuhkan penilaian kreatif mandiri dari pencipta dalam karyanya bahwa kreativitas akan menunjukkan karya asli; 3. Perwujudan. Suatu karya diwujudkan dalam suatu media ekspresi berwujud manakala pembuatnya ke dalam perbanyakan atau rekaman suara oleh atau berdasarkan kewenangan pencipta, secara permanen atau stabil untuk dilihat, direproduksi atau dikomunikasikan dengan cara lain, selama suatu jangka waktu yang cukup lama. Suatu karya yang terdiri dari suara, citra atau keduanya, yang ditransmisikan adalah bertujuan diwujudkan jika suatu perwujudan karya sedang dibuat secara simultan dengan transmisinya.

Lebih lanjut Rahmi Jened menyebutkan syaratsyarat suatu ciptaan (Earl W. Kinter dan Jack Lahr, 1993:60-64): Syarat keaslian atau originality, dalam hal ini syarat originality terkait dengan konsepsi hak cipta sebagai kekayaan atau property, artinya ciptaan tersebut harus benar dari eksistensi pencipta; Persyaratan kreativitas atau creativity terkait dengan kreasi intelektual pribadi artinya ciptaan dibentuk dengan cipta, karsa, dan rasa manusia; Persyaratan perwujudan atau fixation merupakan konsep bentuk material atau material form yang merujuk pada suatu ciptaan sebagai tujuan perlindungan hak cipta. Hak cipta melindungi ekspresi dalam bentuk material, bukan ide atau informasinya.

Perihal ciptaan menurut Harsono Adisumarto, mengemukakan sebagai berikut (Harsono Adisumarto, 1989:8): Disebut suatu ciptaan apabila terkandung dua hal yakni: ekspresi dari suatu ide; originalitas dari suatu ide. Inspirasi seseorang atau beberapa orang berdasarkan pikiran, imajinasi, kecekatan, keterampilan atau keahlian masih berupa ide. Pada fase ini belum memperoleh perlindungan hukum.
Apabila ide tersebut diekspresikan atau dituangkan dalam suatu bentuk tertentu, terbentuk ciptaan dan memperoleh perlindungan hukum, Ekspresi atau penuangan ide dalam bentuk yang khas dan bersifat pribadi, tidak boleh meniru ide orang lain, berarti ciptaan disyaratkan harus original atau asli dari karya pencipta sendiri.

Hal ini sesuai pula dengan yang dikemukakan oleh Eddy Damian sebagai berikut (Eddy Damian, 1999:100): Ciptaan seharusnya mempunyai aspek keaslian original untuk dapat menikmati hak-hak yang diberi oleh undang-undang. Keaslian sangat erat hubungannya dengan bentuk perwujudan suatu ciptaan. Oleh karena itu, suatu ciptaan hanya dapat dianggap asli bila bentuk perwujudannya seperti buku tidak berupa suatu jiplakan plagiat dari suatu ciptaan buku lain yang telah diwujudkan.

Terkait dengan persyaratan tersebut di atas, maka hak cipta hanyalah melindungi ciptaan yang sudah berwujud fixation dan asli originality. Perwujudan logo sebagai ciptaan tidak boleh menjiplak dari karya seni yang telah ada. Dengan kata lain, sebuah logo sebagai ciptaan lahir dari kreatifitas, dan itu adalah salah satu syarat sebagai ciptaan. Selain itu, logo hasil karya seni akan diakui sebagai ciptaan hanya dalam bentuk tertentu. Dalam hal ini logo diakui sebagai ciptaan hanya jika sudah bisa dilihat dan apabila belum berwujud, maka hal tersebut tidak dapat diakui. Dengan terpenuhi persyaratan standard of copyright's ability tersebut di atas, maka suatu logo sebagai hasil karya seni akan mendapat perlindungan hak cipta (Eddy Damian, 1999:66). Hak cipta seperti halnya hak-hak lainnya dalam HKI digolongkan sebagai hak milik perorangan yang tidak berwujud.

Memperhatikan uraian sebagaimana tersebut di atas dapat dijelaskan bahwa logo sebagai hasil karya seni termasuk suatu ciptaan yang dilindungi oleh undang-undang sesuai dengan ketentuan Pasal 12 ayat 1 huruf f UUHC. Sebagai suatu karya seni yang dilindungi, maka bagi pencipta logo hasil karya seni tersebut sebagai pemegang hak cipta yang mempunyai hak yang oleh undang-undang dilindungi.

\section{Perolehan Hak dan Hak Eksklusif Pencipta}

Berdasarkan Pasal 2 ayat 1 UUHC yang dimaksud dengan hak cipta adalah Hak eksklusif bagi Pencipta atau Pemegang Hak Cipta untuk mengumumkan atau memperbanyak hasil ciptaannya, yang timbul secara otomatis setelah suatu ciptaan itu dilahirkan tanpa mengurangi pembatasan menurut peraturan perundang-undangan yang berlaku. Perlindungan akan hak cipta itu bersifat otomatis, sehingga jika 
suatu ciptaan logo hasil karya seni didaftartkan, hal tersebut terkait dengan penyediaan bukti awal atau prima facie evidence atas eksistensi haknya (Rahmi Jened, 2001:30).

Hak Cipta memiliki dimensi hak ekonomi atau economic right dan hak moral atau moral right (Rahmi Jened, 2001:35). Hak ekonomi sebagaimana dimaksud dalam Pasal 2 mencakup hak untuk mengumumkan dan juga memperbanyak. Pengertian pengumuman menurut Pasal 1 angka 5 UUHC adalah pembacaan, penyiaran, pameran, penjualan, pengedaran, atau penyebaran suatu ciptaan dengan menggunakan alat apa pun, termasuk media internet, atau melakukan dengan cara apapun sehingga suatu ciptaan dapat dibaca, didengar, atau dilihat orang lain. Sedangkan perbanyakan menurut Pasal 1 angka 6 UU No. 19 Tahun 2002 adalah penambahan jumlah dari sesuatu ciptaan, baik secara keseluruhan maupun bagian yang sangat substansial dengan menggunakan bahan yang juga sama ataupun tidak, termasuk mengalihwujudkan secara permanen atau temporer.

Hal yang juga sama dikemukakan oleh Harsono Adisumarto yakni hak cipta mencakup (Harsono Adisumarto, 1989:8): Hak ekonomi atau economic right. Hak khusus bagi pencipta untuk mengumumkan atau memperbanyak ciptaannya dan memberi izin untuk itu. Hak ekonomi ini dapat dialihkan kepada pihak lain; Hak moral atau moral right. Hak-hak yang berkenaan dengan mengadakan larangan bagi orang lain mengadakan perubahan karya ciptaannya, larangan mengadakan perubahan judulnya, larangan mengadakan perubahan nama penciptaannya dan hak bagi pencipta untuk mengadakan perubahan karya ciptaannya.

Terdapat dua unsur penting yang terkandung di dalam rumusan pengertian dari hak cipta tersebut, antara lain (Rachmadi Usman, 2003:86) pertama, hak yang dapat utnuk dipindahkan, dialihkan kepada pihak lain dan kedua, hak moral yang terdapat di keadaan bagaimana pun dan dengan jalan apapun tidak dapat ditinggalkan daripadanya, seperti halnya mengumumkan karyanya, menetapkan judulnya, dan juga mencantumkan nama sebenarnya atau nama samarannya dan mempertahankan keutuhan atau integritas ceritanya.

Di samping terdapat dua unsur penting seperti tersebut di atas, di dalam rumusan pengertian hak cipta yang termuat dalam Pasal 2 ayat 1 UU No. 19 Tahun 2002 tersebut, terungkap pengertian dan sifat hak cipta itu, yakni (Rachmadi Usman, 2003:86-87): hak cipta itu merupakan hak yang bersifat khusus, istimewa, atau eksklusif atau exclusive rights yang diberikan kepada pencipta atau pemegang hak cipta. Dengan hak yang bersifat khusus ini berarti tidak ada orang lain yang boleh menggunakan hak tersebut, terkecuali dengan izin pencipta atau pemegang hak cipta yang bersangkutan; hak yang bersifat khusus, tunggal, atau monopoli tadi meliputi hak pencipta atau pemegang hak cipta untuk mengumumkan ciptaannya, memperbanyak ciptaannya, dan memberi izin kepada orang lain untuk mengumumkan atau memperbanyak hasil ciptaannya tersebut; dalam melaksanakan hak yang bersifat khusus ini, baik pencipta, pemegang hak cipta, maupun orang lain yang telah diberi izin untuk mengumumkan atau memperbanyak ciptaannya tadi harus dilakukan menurut peraturan perundangundangan yang berlaku, yang merupakan pembatasanpembatasan tertentu; hak cipta tersebut dianggap sebagai benda bergerak yang bersifat immateriil yang dapat beralih atau dialihkan kepada orang lain, baik untuk seluruh maupun sebagian.

Menurut Budi Agus Riswandi dan M. Syamsudin hak ekonomi umumnya di setiap negara meliputi jenis hak (Bagus Agus Riswandi dan M. Syamsudin, 2004: 4-7): Pertama, Hak Reproduksi atau Penggandaan. Hak pencipta untuk menggandakan ciptaannya, ini merupakan penjabaran dari hak ekonomi si pencipta. Bentuk penggandaan atau perbanyakan ini dapat dilakukan secara tradisional maupun melalui peralatan modern. Hak reproduksi ini juga mencakup perubahan bentuk ciptaan satu ke ciptaan lainnya, misalnya rekaman musik, pertunjukan drama, juga pembuatan duplikasi dalam rekaman suara dan film.

Kedua, Hak Adaptasi. Hak untuk mengadakan adaptasi, dapat berupa penerjemahan dari bahasa satu ke bahasa lain, aransemen musik, dramatisasi dan nondramatik, mengubah menjadi cerita fiksi dari karangan nonfiksi, atau sebaliknya. Hak ini diatur baik dalam Konvensi Berne maupun Konvensi Universal (Universal Copyright Convention).

Ketiga, Hak Distribusi. Hak distribusi adalah hak yang dimiliki pencipta untuk menyebarkan kepada masyarakat setiap hasil dari ciptaannya. Penyebaran tersebut dapat berupa bentuk penjualan, penyewaan, atau bentuk lain yang maksudnya agar ciptaan tersebut dikenal oleh masyarakat. Dari hak distribusi itu dapat dimungkinkan timbul hak baru berupa foreign right, yaitu suatu hak yang dilindungi di luar negaranya.

Keempat, Hak Penampilan atau juga Performance Right. Hak untuk penyajian kuliah, pidato, khotbah, baik melalui cara visual atau presentasi suara, juga menyangkut akan penyiaran film, dan rekaman suara pada media televisi, radio, dan tempat lain yang menyajikan akan tampilan tersebut. Setiap orang 
atau badan yang menampilkan, atau mempertunjukkan suatu karya cipta, harus meminta izin dari si pemilik hak performing tersebut. Keadaan ini terasa menyulitkan bagi orang yang akan meminta izin pertunjukan tersebut, untuk memudahkan hal tersebut maka diadakan suatu lembaga yang mengurus hak pertunjukan itu yang dikenal sebagai Performing Right Society.

Kelima, Hak penyiaran atau juga Broadcasting Right. Hak untuk menyiarkan bentuknya itu berupa mentransmisikan suatu ciptaan oleh peralatan kabel. Hak penyiaran ini bisa meliputi penyiaran ulang dan mentransmisikan ulang. Ketentuan hak ini telah diatur dalam Konvensi Berne, maupun Konvensi Universal, juga konvensi tersendiri misalnya Konvensi Roma 1961; dan juga konvensi Brussel 1974 yang dikenal dengan Relating on the Distribution of Programme Carrying Signals Transmitted by Satellite. Hanya saja di beberapa negara, hak penyiaran ini masih merupakan cakupan dari hak pertunjukan.

Keenam, Hak Program Kabel. Hak ini hampir sama dengan hak penyiaran hanya saja mentransmisikan melalui kabel. Badan penyiaran televisi mempunyai suatu studio tertentu, dari sana disiarkan programprogram melalui kabel pada pesawat para pelanggan. Jadi siaran sudah pasti bersifat komersial.

Ketujuh, Droit de Suite. Droit de suite adalah hak pencipta. Hak ini diatur dalam Pasal 14 bis Konvensi Berne revisi Brussel 1948, yang kemudian ditambah lagi dengan Pasal 14 ter hasil revisi Stockholm 1967. Ketentuan droit de suite ini menurut petunjuk dari WIPO yang mana tercantum dalam buku Guide to the Berne Convention, merupakan hak tambahan. Hak ini bersifat kebendaan.

Kedelapan, Hak Pinjam Masyarakat atau Public Lending Right. Hak ini dimiliki oleh pencipta yang karyanya tersimpan di perpustakaan yaitu dia berhak atas suatu pembayaran dari pihak tertentu karena karyanya yang diciptakannya sering dipinjam oleh masyarakat dari perpustakaan miliknya pemerintah tersebut (Bagus Agus Riswandi dan M. Syamsudin, 2004:4-7)

Pemegang dari hak cipta atas suatu ciptaan logo berbentuk perisai berlatarbelakang matahari bersinar, dengan benteng bagian atas kiri dan kanannya terdapat tulisan Cina Hua dan Yuan, di bawah benteng juga ada tulisan Arise Shine (dikenal logo Aires Shine atau CES) pemegang hak cipta yang selaku pencipta mempunyai hak Droit de Suite adalah hak pencipta. Hak ini mulai diatur dalam Pasal 14 bis Konvensi Berne revisi Brussel 1948, yang kemudian ditambah lagi dengan Pasal 14 ter hasil revisi Stockholm 1967.
Ketentuan Droit de suite ini menurut petunjuk dari WIPO yang mana tercantum dalam buku Guide to the Berne Convention, merupakan hak tambahan. Hak ini bersifat kebendaan.

Hak ekonomi adalah hak yang berkaitan dengan pemanfaatan secara komersial suatu ciptaan. Suatu ciptaan merupakan hasil dari karya intelektual yang diperoleh melalui pengorbanan waktu, tenaga, dan dana. Dilihat dari aspek ekonomi pengorbanan itu merupakan suatu investasi yang perlu dikelola secara komersial untuk mendapatkan pengembalian modal dan memperoleh keuntungan. Semakin bermutu suatu ciptaan semakin tinggi pula potensi nilai komersialnya (Sanusi Bintang, 1998:4).

Mengenai hak ekonomi pada dasarnya dapat juga dialihkan kepada orang lain disertai dengan kewajiban pemberian royalti. Hak moral merupakan manifestasi dari adanya pengakuan manusia terhadap hasil karya orang lain yang sifatnya nonekonomi. Penghargaan moral ini tidak dapat dinilai dengan uang, tetapi berwujud pemberian kekuasaan atau juga wewenang tertentu kepadanya untuk melakukan sesuatu apabila ada orang melanggarnya (Sanusi Bintang, 1998:4).

Hak moral tetap mengikuti dan melekat pada diri dari pencipta dan tidak dapat dialihkan dengan cara apapun juga. Hal ini berkaitan dengan Pasal 24 UUHC sebagai berikut: Pencipta atau ahli warisnya berhak menuntut Pemegang Hak Cipta supaya nama pencipta tetap dicantumkan dalam ciptaannya; Suatu ciptaan tidak boleh diubah walaupun hak ciptanya telah diserahkan kepada pihak lain, kecuali dengan persetujuan pencipta atau dengan persetujuan ahli warisnya dalam hal pencipta telah meninggal dunia; Ketentuan sebagaimana yang dimaksud dalam ayat 2 berlaku juga terhadap perubahan judul dan anak judul ciptaan, pencantuman dan perubahan nama atau nama samaran pencipta; Pencipta tetap berhak mengadakan perubahan pada ciptaannya sesuai dengan kepatutan dalam masyarakat; Hak Cipta dapat dieksploitasi melalui pengalihan hak atau lisensi.

Menurut Pasal 3 ayat 2 UUHC, hak cipta dapat beralih atau juga dialihkan, baik seluruhnya maupun sebagian karena: Pewarisan, Hibah, Wasiat, Perjanjian tertulis, atau sebab-sebab lain yang dibenarkan oleh peraturan perundang-undangan.

Sedangkan eksploitasi melalui perjanjian lisensi diatur di dalam Pasal 45, 46, dan 47 UUHC. Lisensi berasal dari kata license yang berarti izin. Disini pencipta sebagai pemberi lisensi atau juga lisensor memberikan izin kepada si penerima lisensi atau licensee untuk dalam jangka waktu tertentu dan juga dengan syarat tertentu menikmati manfaat ekonomi 
suatu ciptaan yang mana dilindungi hak cipta (Sanusi Bintang, 1998:41).

Lisensi menurut Pasal 1 angka 14 UUHC adalah izin yang diberikan oleh Pemegang Hak Cipta atau Pemegang Hak Terkait pada pihak lain untuk dapat mengumumkan dan/atau perbanyak ciptaannya atau produk Hak Terkait dengan persyaratan tertentu.

Pelisensian hak cipta dapat dilakukan dengan berdasar pada surat perjanjian lisensi, yang mana isinya adalah Pemegang Hak Cipta yang memberikan hak khusus kepada orang lain untuk dapat menikmati manfaat ekonomis suatu ciptaan yang dilindungi oleh hak cipta. Maka dari itu surat perjanjian lisensi itu hanya bersifat pemberian izin atau hak untuk dalam jangka waktu tertentu dengan syarat tertentu menikmati manfaat ekonomis suatu ciptaan yang dilindungi oleh hak cipta. Pada dasarnya, perjanjian lisensi dituangkan dalam suatu akta perjanjian (surat perjanjian) (Rachmadi Usman, 2003:48).

Perjanjian lisensi biasanya tidak dibuat secara khusus. Artinya, pemegang hak cipta tetap dapat melaksanakan hak ciptanya atau juga memberikan lisensi yang sama pada pihak ketiga untuk melakukan perbuatan sebagaimana yang dimaksud pada Pasal 2 UUHC, terkecuali diperjanjikan lain. Meskipun demikian, perjanjian lisensi dapat pula dibuat secara khusus atau eksklusif, yang berarti secara khusus hanyalah diberikan kepada pemegang lisensi saja. Perjanjian lisensi yang mana eksklusif seperti itu pada dasarnya dapat disalahgunakan untuk memonopoli pasar atau meniadakan persaingan sehat di pasar.

Dengan memperhatikan beberapa uraian yang sebagaimana tersebut di atas dapat dijelaskan bahwa logo hasil karya cipta termasuk ciptaan dilindungi oleh undang-undang sesuai dengan ketentuan Pasal 12 ayat 1 huruf $\mathrm{f} U U H C$. Sebagai suatu ciptaan mana yang dilindungi maka pencipta logo hasil karya seni tersebut memperoleh hak eksklusif yaitu hak untuk memperbanyak ciptaan tersebut atau memberikan ciptaan tersebut kepada orang lain. Ciptaan berupa logo hasil karya seni tersebut merupakan suatu ide yang diwujudkan sehingga merupakan suatu ciptaan yang mendapat perlindungan hukum. Mengenai pihak yang menciptakan logo karya seni berbentuk perisai berlatarbelakang matahari bersinar. Dengan benteng bagian atas kiri dan kanannya terdapat tulisan Cina Hua dan Yuan. Di bawah benteng juga ada tulisan Arise Shine tersebut diperebutkan oleh Yayasan Hwa Ing Fonds yang mengaku sebagai pemilik logo dan menggunakan logo sebagai suatu karya cipta tersebut sejak tahun 1929, sedangkan Budi Haliman Halim mengklaim logo sebagai ciptaan tersebut dengan alasan telah mendaftarkan logo sebagai suatu ciptaan tersebut pada Dirjen HKI.

\section{Kasus Posisi dari Hak Yayasan Hwa Ing Fonds atas Logo Sebagai Ciptaan Berbentuk Perisai Berlatarbelakang Matahari Bersinar dengan Benteng Bagian Atas Kiri dan Kanannya Terdapat Tulisan Cina Hua dan Yuan}

Logo sebagai suatu ciptaan yang berbentuk perisai berlatarbelakang matahari bersinar dengan benteng bagian atas kiri dan kanannya terdapat tulisan Cina Hua dan Yuan disengketakan antara Yayasan Hwa Ing Fonds dengan Budi Haliman Halim sebagai pendiri pusat pelatihan bahasa KOTA BAHASA, pelatihan tersebut adalah pelatihan bahasa Inggris, Mandarin, Jepang, Perancis, dan Jerman yang berpusat di Ruko Sultan Agung KAV 15 Jl. Sultan Agung No. 104106 Semarang. Sejatinya kasus sengketa hak cipta ini bermula pada 26 Juli 2003 lalu, pada saat itu Budi Haliman Halim memasang logo tersebut di papan KOTA BAHASA yang merupakan salahsatu cabang pusat pelatihan miliknya yang terletak di Jl. Gang Besen No. 28 Semarang. Yayasan Hwa Ing Fonds mengklaim Logo berbentuk perisai berlatarbelakang matahari bersinar dengan benteng bagian atas kiri dan kanannya terdapat tulisan Cina Hua dan Yuan dengan alasan telah menggunakan ciptaan tersebut sejak tahun 1929 sedangkan Budi Haliman Halim mengklaim Logo berbentuk perisai berlatarbelakang matahari bersinar dengan benteng bagian atas kiri dan kanannya terdapat tulisan Cina Hua dan Yuan karena telah mendaftarkan ciptaan tersebut pada Dirjen HKI tertanggal pada 22 Mei 2001. Hal ini berarti bahwa klaim dari masing-masing pihak tersebut sama-sama mempunyai landasan hukum yang dapat digunakan sebagai dasar untuk mempertahankan haknya atas ciptaan logo tersebut.

Penyelesaian dengan cara damai tidak membawa hasil, akhirnya Yayasan Hwa Ing Fonds mensomasi dan melaporkan Budi Haliman Halim pada pihak kepolisian, dan kasus itu pun pada akhirnya bergulir ke meja hijau dan hasilnya Budi Haliman Halim dinyatakan bersalah melakukan perbuatan melanggar hak cipta serta didakwa melakukan tindak pidana sebagaimana di atur dalam Pasal 72 ayat 1 dan ayat 2 UUHC. Bahkan Jaksa Penuntu Umum pun sudah menuntut Budi satu tahun penjara.

\section{Analisis Masalah}

Logo yang berbentuk perisai berlatarbelakang matahari bersinar dengan benteng bagian atas kiri dan kanannya terdapat tulisan Cina Hua dan Yuan 
merupakan suatu ciptaan sebagaimana pada Pasal 1 angka 3 UUHC adalah hasil setiap karya pencipta yang man menunjukkan keasliannya dalam lapangan ilmu pengetahuan, seni, ataupun sastra. Pihak yang menciptakan karya cipta tersebut disebut pencipta, menurut Pasal 1 angka 2 UUHC, yang menentukan pencipta adalah seorang atau beberapa orang secara bersama-sama yang atas inspirasinya melahirkan suatu ciptaan yang berdasarkan kemampuan pikiran, imajinasi, kecekatan, ketrampilan, atau keahlian yang dituangkan ke dalam bentuk yang khas dan bersifat pribadi. Hal ini berarti bahwa logo berbentuk perisai berlatarbelakang matahari bersinar dengan benteng bagian atas kiri dan kanannya terdapat tulisan Cina Hua dan Yuan sebagai suatu ciptaan tentunya ada pihak yang memiliki ide dan ide tersebut diwujudkan dalam bentuk suatu ciptaan. Hal ini sesuai dengan apa yang dikemukakan oleh Harsono Adisumarto, sebagai berikut: Dikatakan sebagai suatu ciptaan bilamana terkandung dua hal, yakni: Ekspresi dari suatu ide; Originalitas ide (Harsono Adosumarto, 1989:8).

Inspirasi seseorang atau pada beberapa orang yang mana berdasarkan pikiran, imajinasi, kecekatan, keterampilan atau keahlian masih berupa ide. Pada fase ini menurut Harsono Adisumarto belum dapat untuk memperoleh perlindungan hukum. Apabila ide tersebut diekspresikan atau dituangkan dalam suatu bentuk tertentu, maka terbentuklah ciptaan dan memperoleh perlindungan hukum (Harsono Adosumarto, 1989:8).

Ekspresi atau penuangan ide kedalam suatu bentuk yang khas dan bersifat pribadi, tidak boleh meniru ide orang lain, berarti ciptaan disyaratkan haruslah original atau asli dari karya pencipta sendiri (Harsono Adosumarto, 1989:8). Hal ini sesuai pula dengan yang dikemukakan oleh Eddy Damian bahwa suatu ciptaan harus mempunyai keaslian atau original untuk dapat menikmati hak-hak yang diberikan undang-undang. Keaslian sangat erat hubungannya dengan bentuk perwujudan suatu ciptaan. Karena itu, suatu ciptaan hanya dapat dianggap asli bila bentuk perwujudannya seperti buku tidak berupa suatu jiplakan atau plagiat dari suatu ciptaan buku lain yang telah diwujudkan (Eddy Damian, 1999:100).

Logo berbentuk perisai berlatarbelakang matahari bersinar dengan lambang benteng bagian atas kiri dan kanannya terdapat tulisan Cina bertuliskan Hua dan Yuan merupakan suatu ide yang diekspresikan dan original, sehingga memenuhi unsur ciptaan, bukan berarti dapat memperoleh perlindungan sebagai suatu ciptaan. Karena undang-undang hanya memberikan perlindungan pada suatu ciptaan jika termasuk ciptaan salah satu di antaranya yaitu seni rupa dalam segala bentuk seperti seni lukis, gambar, seni ukir, seni kaligrafi, seni pahat, seni patung, kolase dan seni terapan sebagaimana Pasal 12 huruf f UUHC.

Ciptaan dalam bentuk logo yang berbentuk perisai berlatarbelakang matahari bersinar dengan benteng bagian atas kiri dan kanannya terdapat tulisan Cina Hua dan Yuan yang lahir pada saat sejak adanya ide yang mana dituangkan dan diekspresikan dalam suatu bentuk tertentu yang bersifat khas dan khusus, serta originalitas suatu ide, sehingga berbentuk ciptaan dan memperoleh perlindungan hukum. Hal ini sesuai dengan yang dikemukakan oleh Ridwan Khairandy bahwa pada dasarnya sebuah ciptaan itu ada atau lahir bersamaan dengan lahirnya suatu karya cipta atau ciptaannya. Hak cipta atas ciptaan di bidang ilmu pengetahuan, seni dan sastra lahir dan dimiliki bukan karena diberikan negara. Akan tetapi karena dari segi hukum sulit mengetahui kapan persisnya suatu ciptaan itu dilahirkan maka untuk keperluan saat mulainya perlindungan hukum atas hak cipta, ciptaan tersebut dianggap mulai ada sejak pertama kali diumumkan. Artinya dibacakan, disuarakan, disiarkan atau disebarluaskan dengan alat apapun dan dengan cara apa pun, sehingga dapat dibaca, didengar atau dilihat orang lain (Ridwan Khairandy, 1999:265). Sehubungan dengan adanya pendaftaran hak milik intelektual menurut Ridwan Khairandy membedakannya dua sistem, yaitu sistem deklaratif dan sistem konstitutif. Sistem deklaratif atau first to use principle, titikberatnya diletakkan pada pemakaian pertama. Siapa yang pertama kali memakai suatu ciptaan, dialah yang dianggap berhak atas ciptaan yang bersangkutan. Pemakaian yang pertama itulah yang melahirkan hak atas ciptaan. Dalam sistem deklaratif ini pendaftaran ciptaan hanya memberikan dugaan atau juga sangkaan hukum (rechtsvermoeden atau presumption iuris) bahwa orang yang mana telah mendaftarkan ciptaan itu adalah pemakai pertama dan orang yang berhak atas ciptaan yang bersangkutan. Apabila ada orang lain dapat membuktikan bahwa ialah pemakai pertama ciptaan yang bersangkutan, maka pendaftaran itu bisa dibatalkan pengadilan. Dalam sistem deklaratif, fungsi pendaftaran ciptaan hanya memudahkan pembuktian bahwa dia yang diduga sebagai pemilik yang sah karena dia adalah pemakai pertamanya.

Dalam sistem konstitutif atau juga first to file, pendaftaran hak atas merek. Dengan kata lain, orang yang berhak atas ciptaan adalah orang yang telah mendaftarkan ciptaannya itu. Pendaftar merupakan satu-satunya orang yang berhak secara eksklusif atas 
ciptaan yang bersangkutan, dan orang lain tidak dapat memakainya tanpa ijin dari yang bersangkutan.

Didalam stelsel konstitutif letak titik berat ada tidaknya hak cipta tergantung pada pendaftarannya. Jikalau didaftarkan (dengan sistem konstitutif) hak cipta itu diakui keberadaannya secara de jure dan de facto sedangkan pada stelsel deklaratif titik beratnya diletakkan pada anggapan sebagai pencipta terhadap hak yang didaftarkan itu, sampai orang lain dapat membuktikan sebaliknya. Dengan rumusan lain, pada sistem deklaratif sekalipun hak cipta itu didaftarkan undang-undang hanya mengakui seolah-olah yang bersangkutan sebagai pemiliknya, secara de jure haruslah dibuktikan lagi, jika ada orang lain yang menyangkal hak tersebut (Saidin, 2004:89). Hal ini berarti bahwa ciptaan tinbul dengan sendirinya sesuai dengan yang dikemukakan oleh Eddy Damian bahwa ciptaan itu timbul dengan sendirinya atau otomatis; tidak selalu perlu diumumkan untuk memperoleh hak cipta; hak cipta suatu ciptaan merupakan suatu hak yang diakui hukum atau legal right yang harus dipisahkan dan harus dibedakan dari penguasaan fisik suatu ciptaan; hak cipta bukan hak mutlak atau absolut (Eddy Damian, 1999:103-106). Ciptaan dalam bentuk logo berbentuk perisai berlatarbelakang matahari bersinar dengan benteng bagian atas kiri dan kanannya terdapat tulisan Cina Hua dan Yuan timbul dengan sendirinya atau otomatis artiya bahwa dengan adanya wujud dari suatu idea, suatu ciptaan lahir. Dengan demikian ciptaan itu lahir dengan sendirinya sejak dituangkannya ide dalam suatu bentuk yang khas dan bersifat pribadi. Hal ini sesuai pula dengan yang dikemukakan oleh Muhamad Djumhana bahwa hak cipta ada secara otomatis ketika suatu ciptaan lahir dari seorang pencipta (Muhamad Djumhana dan Djubaedillah, 1997:85).

Ciptaan yang berbentuk logo berbentuk perisai berlatarbelakang matahari bersinar dengan benteng bagian atas kiri dan kanannya terdapat tulisan Cina Hua dan Yuan tersebut digunakan oleh Yayasan Hwa Ing Fonds sejak tahun 1929, yang berarti bahwa ciptaan tersebut telah ada dalam arti ide tersebut telah diwujudkan sejak tahun 1929, namun Yayasan Hwa Ing Fonds belum atau tidak mendaftarkan ciptaan dalam bentuk logo tersebut. Pendaftaran suatu ciptaan bukan merupakan keharusan, dengan didaftarkan akan memudahkan pembuktiannya jika terjadi suatu sengketa mengenai hak atas suatu ciptaan. Hal ini sesuai dengan yang dikemukakan oleh Muhamad Djumhana sebagai berikut, pendaftaran hak cipta tidak merupakan keharusan, karena tanpa pendaftaran pun hak cipta dilindungi, hanya mengenai ciptaan yang tidak didaftarkan akan sukar, dan memakan waktu pembuktian hak ciptanya daripada ciptaan yang telah didaftarkan.

Budi Haliman Halim mengklaim bahwa ciptaan dalam bentuk logo berbentuk perisai berlatarbelakang matahari bersinar dengan benteng bagian atas kiri dan kanannya terdapat tulisan Cina Hua dan Yuan merupakan haknya karena dirinya telah mendaftar pada Kantor Ditjen HKI. Pendaftaran suatu ciptaan bagi pendaftaran atas perolehan perlindungan hukum meskipun pendaftaran ciptaan bukan merupakan suatu keharusan, namun perlu diketahui bahwa ciptaan yang didaftar tersebut haruslah asli atau orisinal, jika kenyataannya ciptaan dalam bentuk Logo berbentuk perisai berlatarbelakang matahari bersinar dengan benteng di bagian atas kiri dan kanannya terdapat tulisan Cina Hua dan Yuan tersebut telah digunakan oleh Yayasan Hwa Ing Fonds sejak tahun 1929 yang berarti bahwa ciptaan yang didaftarkan oleh Budi Haliman Halim tersebut bukanlah orisinal atau asli, melainkan suatu ciptaan yang telah ada sebelumnya, yang kemudian didaftarkan oleh Budi Haliman Halim, yang berarti bahwa sebagai pendaftar yang beritikad tidak baik.

Budi Haliman Halim yang mendaftarkan suatu ciptaan padahal sebagai pendaftar bertitikad baik, maka kepadanya dapat dikenakan sanksi, atas dasar pelanggaran akan hak cipta. Perihal pelanggaran hak cipta, pada umumnya berkisar pada dua hal pokok, menurut Muhamad Djumhana yaitu dengan sengaja dan tanpa hak mengumumkan, memperbanyak atau memberi izin untuk itu. Salah satu contoh pelanggaran tersebut adalah berupa dengan sengaja melanggar larangan untuk mengumumkan setiap ciptaan yang bertentangan dengan kebijaksanaan oleh pemerintah di bidang pertahanan dan juga keamanan negara, kesusilaan serta ketertiban umum; dan dengan sengaja memamerkan, mengedarkan atau menjual kepada umum sesuatu ciptaan atau barang hasil pelanggaran hak cipta (Muhammad Djumhana dan Djubaedillah, 1997:90). Dengan demikian pelanggaran hak cipta dapat dituntut dalam perkara pidana, selain itu hakim dapat memerintahkan untuk menghentikan kegiatan perbuatan, perbanyakan, penyiaran, pengedaran, dan penjualan ciptaan atau barang yang merupakan hasil pelanggaran hak cipta, sesuai dengan ketentuan Pasal 49 ayat 1 jo Pasal 72 ayat 1 UUHC, yang menentukan pelaku memiliki hak eksklusif untuk memberi ijin atau melarang pihak lain yang tanpa persetujuannya membuat, memperbanyak, atau menyiarkan rekaman suara dan/atau gambar pertunjukkannya. Sedangkan menurut Pasal 72 ayat 1 UUHC menentukan bahwa 
barang siapa dengan sengaja tanpa hak melakukan perbuatan sebagaimana dimaksud dalam Pasal 2 ayat 1 atau Pasal 49 ayat 1 dan ayat 2 dipidana dengan pidana penjara paling singkat 1 (satu) bulan dan/atau denda paling sedikit Rp. 1.000.000,00 (satu juta rupiah), atau pidana penjara paling lama 7 (tujuh) tahun dan/atau denda paling banyak Rp. 5.000.000.000,00 (lima milyar rupiah). Meskipun pelaku pelanggaran hak cipta telah diberi sanksi dalam perkara pidana, pihak yang dirugikan dapat menggugat ganti kerugian secara keperdataan terhadap pelaku. Hal ini sejalan dengan ketentuan Pasal 56 UUHC, yang menentukan bahwa pemegang hak cipta berhak mengajukan gugatan ganti rugi kepada Pengadilan Niaga atas pelanggaran hak ciptanya dan meminta penyitaan terhadap benda yang diumumkan atau hasil perbanyakan ciptaan itu; Pemegang hak cipta juga berhak memohon kepada Pengadilan Niaga agar memerintahkan penyerahan seluruh atau sebagian penghasilan yang diperoleh dari penyelenggaraan ceramah, pertemuan ilmiah, pertunjukan atau pameran karya, yang merupakan hasil pelanggaran hak cipta; Sebelum menjatuhkan putusan akhir dan untuk mencegah kerugian yang lebih besar pada pihak yang haknya dilanggar, hakim dapat memerintahkan pelanggar untuk menghentikan kegiatan pengumuman dan/atau perbanyakan ciptaan atau barang yang merupakan hasil pelanggaran hak cipta.

Berdasarkan uraian sebagaimana tersebut di atas dapat dijelaskan bahwa Yayasan Hwa Ing Fonds yang telah menggunakan ciptaan dalam bentuk logo berbentuk perisai berlatarbelakang matahari bersinar dengan benteng bagian atas kiri dan kanannya terdapat tulisan Cina Hua dan Yuan sejak tahun 1929 dan selama menggunakan ciptaan logo tersebut tidak terdapat pihak lain yang mengajukan keberatan, yang berarti Yayasan Hwa Ing Fonds sebagai pemegang hak cipta atas ciptaan logo tersebut. Sebagai pemegang hak cipta, maka Yayasan Hwa Ing Fonds mempunyai hak eksklusif atas ciptaan tersebut yaitu menggunakan sendiri ciptaan atau memberikan hak kepada pihak lain untuk menggunakan ciptaan tersebut. Yayasan Hwa Ing Fonds menggunakan sendiri hasil ciptaan tersebut, apabila kenyataannya Budi Haliman Halim mendaftarkan ciptaan dan pendaftarannya dikabulkan, maka Yayasan Hwa Ing Fonds yang merasa dirugikan dan sebagai pencipta dan pemegang hak cipta dapat menyelesaikan permasalahannya dengan melaporkan Budi Haliman Halim kepada pihak kepolisian untuk dilakukan penyidikan atas dasar melanggar hak cipta yaitu menggunakan ciptaan tanpa izin atau persetujuan dari pencipta sesuai dengan Pasal 72 UUHC.
Selain itu juga dapat menggugat ganti kerugian serta pembatalan pendaftaran ciptaan tersebut ke Pengadilan Niaga sesuai dengan ketentuan Pasal 56 UUHC, yang mana menentukan bahwa pemegang hak cipta berhak mengajukan gugatan ganti rugi kepada Pengadilan Niaga atas adanya pelanggaran hak ciptanya dan meminta penyitaan terhadap benda yang diumumkan atau hasil perbanyakan ciptaan itu; Pemegang hak cipta juga berhak memohon kepada Pengadilan Niaga agar memerintahkan penyerahan seluruh atau sebagian penghasilan yang diperoleh dari penyelenggaraan ceramah, pertemuan ilmiah, pertunjukan atau pameran karya, yang merupakan hasil pelanggaran hak cipta.

\section{PENUTUP \\ Kesimpulan}

UUHC memberikan perlindungan kepada suatu ciptaan dalam bidang ilmu pengetahuan, seni, dan sastra yang sebagaimana sudah diatur dalam pasal 12 UUHC. Dan juga perlindungan hukum diberikan kepada suatu ciptaan yang mana tidak atau belum didaftarkan ataupun diumumkan, dan bukan hanya sekedar ide atau gagasan, tetapi sudah merupakan suatu bentuk dari kesatuan yang nyata-nyata terlahir sejak ide tersebut dituangkan dalam suatu bentuk yang mempunyai ciri khas dan khusus sesuai Pasal 12 ayat 3 UUHC.

Yayasan Hwa Ing Fonds masih berhak atas logo berbentuk perisai berlatarbelakang matahari bersinar dengan benteng bagian atas kiri dan kanannya terdapat tulisan Cina Hua dan Yuan yang digunakan sejak 1929. Budi Haliman Halim melakukan pendaftaran ciptaan yang telah ada sebelumnya yang berarti bahwa ciptaan yang didaftarkan tersebut tidak orisinil, yang oleh UUHC tidak memperoleh perlindungan hukum. Sedangkan logo berbentuk perisai berlatarbelakang matahari bersinar dengan benteng bagian atas kiri dan kanannya terdapat tulisan Cina Hua dan Yuan diakui sebagai ciptaan dari Yayasan Hwa Ing Fonds, ciptaan tersebut diakui bukan karena pendaftaran.

\section{Rekomendasi}

Untuk memberi perlindungan dan memberikan jaminan terhadap Hak Cipta kepada yang menciptakan atau si penciptanya atau atas si pemegang hak tersebut, maka aparat penegak hukum haruslah melakukan penyidikan secara tuntas dari setiap hasil penindakan terhadap kasus-kasus pembajakan yang ada agar para pembajak takut dan tidak melakukan pembajakan, dan memberikan sanksi yang berat sebagai daya cegah bagi pelaku lainnya. 


\section{DAFTAR PUSTAKA}

\section{Buku:}

Adisumarto, Harsono, 1989, Hak Milik Intelektual Khususnya Hak Cipta, Jakarta: Akademika Pressindo.

Bintang, Sanusi, 1998, Hukum Hak Cipta, Bandung: Citra Aditya Bakti.

Damian, Eddy, 1999, Hukum Hak Cipta menurut Beberapa Konvensi Internasional, UndangUndang Hak Cipta 1997 dan Perlindungan terhadap Buku serta Perjanjian Penerbitnya, Bandung: Alumni.

Djumhana, Muhamad dan Djubaedillah, 1997, Hak Milik Intelektual, Sejarah, Teori dan Prakteknya Di Indonesia, Bandung: Citra Aditya Bakti.

Hutauruk, 1982, Peraturan Hak Cipta Nasional, Jakarta: Erlangga.

Khairandy, Ridwan, et. All., 1999, Pengantar Hukum Dagang Indonesia 1, Jakarta: Gama Media.
Kinter, Earl W. dan Jack Lahr, 1993, An Intellectual Property Law Primer, Clark Boardman, New York. Dikutip dari Rahmi Jened, 2001, Perlindungan Hak Cipta Pasca Persetujuan Trips, Surabaya: Yuridika Press Fakultas Hukum Universitas Airlangga Surabaya.

Riswandi, Budi Agus dan M. Syamsudin, 2004, Hak Kekayaan Intelektual dan Budaya Hukum, Jakarta: Raja Grafindo Persada.

Saidin, 2004, Aspek Hukum Hak Kekayaan Intelektual (Intellectual Property Rights), Jakarta: Raja Grafindo Persada.

Usman, Rachmadi, 2003, Hukum Hak atas Kekayaan Intelektual, Bandung: Alumni.

\section{Peraturan Perundang-undangan:}

Kitab Undang-Undang Hukum Perdata.

Undang-Undang No. 19 Tahun 2002 tentang Hak Cipta. 